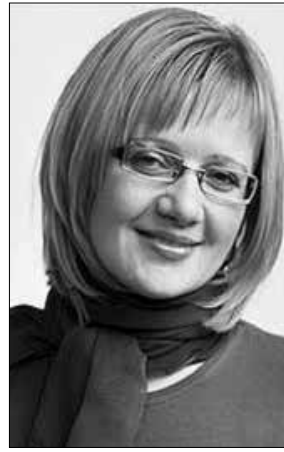

https://doi.org/10.24101/logos.2019.33

\title{
SVITLANA POLYUHA
}

Ukrainos kataliku universitetas Lvove, Ukraina

Ukrainian Catholic University of Lviv, Ukraine

\section{GRAMATINIO TERMINO APIBÜDINIMO NACIONALINIS SUVOKIMAS PER ANTIKINĖS TRADICIJOS APIBRĖŽTI}

\author{
National Perception of the Definition \\ of the Grammatical Term through the Reception \\ of the Ancient Tradition
}

\begin{abstract}
SUMMARY
The article analyzes the stages of formation and development of Ukrainian morphological terminology as influenced by the Greek-Roman antique tradition. The article emphasizes that the determinative influence of the ancient tradition on later European linguistics is largely due to the orientation of the tradition towards the realization of logical categories. This orientation in the language provide it with a potentially universal range. The generalization of the analyzed examples of grammatical terms in the modern Ukrainian language shows that when Ukrainian grammatical terminology was being created, the Greek-Latin grammatical terms were a kind of "prototype". Theoretical generalizations will be used in further research on word formation.
\end{abstract}

\section{SANTRAUKA}

Straipsnyje nagrinėjami Ukrainos morfologinės terminijos formavimosi ir raidos etapai, susiformavę pagal graikų-romėnų antikines tradicijas. Pabrėžiama, jog antikinės tradicijos įtaka Europos kalbotyrai priklausė nuo to, kad ji buvo orientuota į loginių kategorijų realizavimą per kalbą. Gramatinių terminų pavyzdžių šiuolaikinèje ukrainiečių kalboje analizė rodo, kad kuriant Ukrainos gramatinę terminiją, graikų ir lotynų kalbos gramatikos terminai tapo „prototipu“. Teoriniai apibendrinimai bus naudojami toliau tiriant žodžio formavimą. 


\section{INTRODUCTION}

The theory of parts of speech arose in ancient Greek science first as a philosophical, and subsequently as a philological branch, and it gradually transferred to the Latin soil and assimilated in living European languages. Linguistic terminology reflects national linguistic traditions, and its research at various stages confirms the influence of the achievements of European linguistics, which manifests itself in genetic, wordformation changes of terms.

The relevance of the work is determined by the need to clarify the role of ancient grammatical science in the development of national peculiarities of terminology and trends of the ancient tradition influence on the formation of domestic terminology of morphology, justification of the grammatical description features of the old and modern Ukrainian literary language.

Analysis of recent research and publications. Scientific dynamic analysis of the formation and development of system parameters of ancient grammatical terminology became the object of research of many scientists. The attention of linguists is attracted to particular theoretical views as separate representatives of ancient linguistics, as well as entire grammatical schools and directions. Certain aspects of this problem have been considered by Yu. Kobiv, R. Olenych, M. Seniv, L. Zvonska, S. Polyuha, B. Bartnicka-Dąbkowska, S. Heinimann, H. Steinhtal. Great interest in ancient linguistic primary sources and their influence on the creation of national grammar were shown by H. Frisk, E. Ising, and A. Walde.

The research methods are conditioned by the necessity to characterize extralinguistic factors in the development of Ukrainian linguistics, semantic series of morphology terms, historical changes in their semantic structure, determining the relationship between names of the parts of speech in the antique times and in the period of formation of Ukrainian grammatical science, tracing methods, etc. To achieve this goal, a descriptive scientific method was used to determine the origin of the terminological lexemes - the comparativehistorical and comparative method. The subject of the study is the morphological terms recorded in the works of ancient Greek, Roman and Ukrainian grammarians.

The purpose of this publication is to comprehensively analyse the influence of the ancient linguistic tradition on the formation of the Ukrainian grammatical terminology in the aspect of modern national term creation. The above-mentioned purpose includes analysis of the development of terminological science in Ukraine and the study of ancient Greek and Roman grammar treatises as an integral part of ancient grammatical science in the context of the formation of the Ukrainian morphological terminology system. 


\section{GRAMMATICAL THEORY IN THE PHILOSOPHICAL SCHOOLS OF ANCIENT GREECE OF THE CLASSICAL PERIOD}

Traditionally, the era of term creation originates in the ancient world. The Greek grammatical theory had gone a long way to development and reached its greatest heyday in the Hellenistic period when grammar was separated from philosophy and became a separate scientific discipline with its own subject of research. For two millennia, grammatical knowledge had been systematized and presented in the system of parts of speech. The state of all aspects of the theory of parts of speech depends on the system of views of a scientist of a certain period of the development of scientific thought, from his native language, from his possession of other languages, from his scientific environment and its influence on him during the period of his studies and the formation of his outlook. Besides, it also depends on the development of science, especially philosophy and natural science. That is why the theory of parts of speech is still not clearly associated with a certain branch of linguistics, but traditionally parts of speech are considered within the grammatical, or rather, morphological description of languages (Полюга 2013).

The question of the suitability of the ancient scheme of parts of speech for modern linguistics is relevant in all fundamental studies of the theory of grammar and, in particular, the theory of parts of speech. Greek philosophers introduced the concept of parts of speech into science, proposed a method of approach to the description of their native language, and developed a scheme of the eight-member system of parts of speech.
Among the ancient schemes of the classification of parts of speech. O. Espersen highlights the Marc Terentii Varro system, the basis of which is only one morphological principle - the presence or absence of cases/times. However, this scheme is oriented exclusively to the Latin language and can not be used either for modern languages derived from the Latin language structure or for languages of a different type, such as Eskimo (Есперсен 1958: 62).

The orientation of many systems of parts of speech on the basis of the 'onoma-rhema' is primarily explained by the heterogeneity of the classification criteria of this theory. The logical thinking of ancient Greek scholars from Aristotle and Plato to Dionysius of Thrace and Apollonius Diskole makes it possible to understand the traditional grammar according to the criteria of classification into parts of speech and relieves the need to invent new combinations that are perceived at the subconscious level. Interpretation of the teaching of parts of speech began with Plato and included the addition of certain emphases dictated by the needs of society and science of the relevant period, as well as the language on which the research was conducted. Thus, traditionally, under the parts of speech, we understand the lexical-grammatical classes of words that are distinguished on the basis of the commonality of their syntactic, morphological and semantic features, and the leading one is recognized as morphological, since each part of speech is characterized by a special system of grammatical (morpholog- 
ical) categories covering all the words of a certain part speech or the core of these words (Амирова 1975: 508).

Ancient Greek philosophers investigated not only general problems of language but also some aspects of it. The development of logic, logical analysis of judgments was reflected in language theories, in particular in attempts to classify words into parts of speech based on certain characteristics. Plato in the " $K \rho \alpha$ $\tau v$ io $\varsigma^{\prime \prime}$ (Kratil) dialogue seeks to classify parts of speech by separating the name and verb. He calls the verb something which refers to action, and the name is something which performs this action (Platonis Opera 1910: T. 2, 299).

However, the logic-grammatical concept of language is more consistently set forth in the writings of Aristotle: name

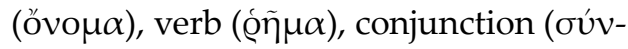
$\delta \varepsilon \sigma \mu о \varsigma)$, member (ă@Ө@ov). In his trea-

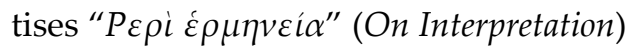

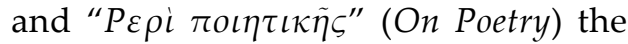
philosopher provides the definition of a name: ővo $\mu \alpha \delta \dot{\varepsilon} \dot{\varepsilon} \sigma \tau \iota \phi \omega v \dot{\eta} \sigma v v \theta \varepsilon \tau \dot{\eta} \sigma \eta-$

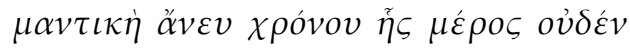

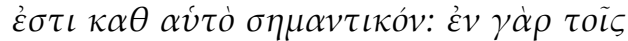

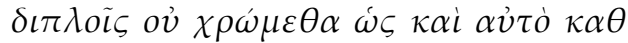

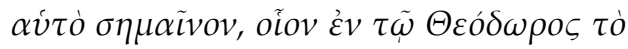
$\delta \omega \rho o \varsigma$ ov $\sigma \eta \mu \alpha i v \varepsilon \iota$ (Aristoteles Poetik
1982: 1457a, 10-15): name is a word with a nominal value without a time shade, individual parts of which have no independent value. As we can see, this interpretation does not reveal the essence lexical meaning of the name and its grammatical features but rather describes the name as a word which lacks some features: time-independent value of its parts. In the same treatise Aristotle (Aristoteles Poetik 1982: 1457a, 15-20) a verb is defined as a word, which means extra time; part of it, taken separately, has no independent meaning, like in names. Thus, the verb is different from the name because of the presence of time shade and ability to predicate, in other words, according to Aristotle semanticsyntactic criteria is the basis for determining the essence of a verb.

The philosopher identified parts of speech and the members of the sentence with the categories of logic, that is, the name was idintefied with the logical subject, the verb - with the logical predicate, and the sentence was considered as a statement. Lexem $\lambda o ́ \gamma o \varsigma$ was the common name of the sentence, therefore

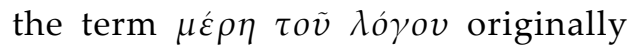
meant not "parts of speech", but "parts of the sentence".

\section{GRAMMAR AS INDEPENDENT SCIENCE \\ AS A RESULT OF PHILOSOPHICAL AND CULTURAL CONCEPT BY REPRESENTATIVES OF THE ALEXANDRIAN SCHOOL}

In the period of antiquity, the Alexandrian system of parts of speech became popular. Grammar at that time became an independent science with its own object of research and terminology. The system of Alexandrian grammatical doctrine formed the works of Aristarchus of Samothracy, his disciple Dionysius of Thracian, Apollonius Diskole and others. R. Olenych, a researcher of the ancient scientific heritage, notes the main feature of the Alexan- 
drian school - an analogy, which was understood as a certain symmetry, the similarity of language phenomena, which was considered the only correct criterion for the study of the Greek language (Оленич 1962: 131-133). Yes, and Dionysius Thracian emphasized that the similarity in the language reflects its ideal starting state.

The doctrine of Apollonius Diskole had a great influence on the creation of the grammatical theory of Priscian and on the Roman grammatical terminology science IV-V centuries. Some of its elements and ideas have even become, in a certain way, the property of European, including Ukrainian, linguistic science. History of the formation and development of Latin grammar terminology is largely associated with the leading role of ancient Greek science in the Roman civilization (culture, philosophy, literature). Quintus Remmi Palemont introduced the Alexandrian grammar system in Rome, and it survived throughout the history of Roman grammar.
Palemont's predecessor, Markus Terentius Varro (116-27 BC) the author of the linguistic work "De lingua Latina" (About Latin), classified parts of speech according to the morphological principle. In grammar he used a somewhat peculiar division into four parts of speech: 1) pars, quae habet casus (part of speech having the case); 2) pars, quae habet tempora (part of speech that has times); 3) pars in qua est utrumque (part of speech that has both one and the other); 4) pars, quae habet neutrum (part of speech that has neither one nor the other) (Varro M. T. 1910: 68).

Priscian's treatise "Institutiones Grammaticae" (Grammatical Guidelines), created in the fifth century, became the apogee of the development of the Roman grammatical science. This scientific study in its volume and content can be considered a synthesis of ancient grammatical science. (Grammatici Latini 1857: II). He used the well-known at that time in Roman grammar terms-names borrowed from Palemont and Dionysius.

\section{INFLUENCE OF ANCIENT TRADITION ON THE FORMATION OF GRAMMAR TERMINOLOGY OF UKRAINIAN LANGUAGE}

The Greec-Roman classification of parts of speech was adopted by the grammatical science of many European nations and for a long time had been considered a model. But with the development of linguistics, in particular with the advent of the comparative-historical method, a critical review of the traditional classification of parts of speech began. During the formation of the Ukrainian grammatical thought, Ukrai- nian scientists could solve these problems during all periods of our language functioning, focusing on the establishment of grammatical terminology and its morphological subsystem, borrowed from the first Slavic grammatists from Greek and Roman scholars.

Books "Граммиатіка доброглаголиваго еллино-словенскаго языка", "Грамматіка словенска" by Lavrentiy Zyzaniya "Грамматіки Славенския правилное Сунтал- 
$\mathcal{M} a$ " by Meletiy Smotrytskyi and "Грамматыка словенская" by I. Uzhevych were considered the first important scientific work that gave impetus to the development of Ukrainian linguistics.

"Грамматіка" of 1591 for a long period of time served the students of the Eastern Slavic schools as the only textbook of the Greek language intended to confirm the equivalence of the Greek and Church Slavonic languages and to draw contemporaries' attention to the writing of special grammar of the Church Slavonic language.

The authors of this manual not only fixed the terminology developed by the ancient grammatists but also perfected it and created a large number of new terms in the Slavic grammatical terminology, which became a model for the formation of the structure of the grammar of later authors (Німчук 1982: 25). The term "местоимя" (pronoun) was changed to refer to the pronoun, and the polysemic term "peub" (speech), which in the Ukrainian language of the XVI century meant "thing, matter, language" and was used to denote the verb, was replaced by the Church Slavonic "zлаголь" (verb). To name the case, the authors consistently used the term "падежъ" (case) instead of the Greek term "naxerie". The newly- grammatical terms introduced by the students of the Lviv Adelfotess School also included the lexeme "склоненіе" which replaced the Greek

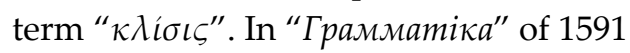
the category of the gender and numbers is described in detail, and in the system of the verb - the category of a kind, state (залогъ), a person (^ице), time (время), as well as a conjunction (супружество).

The new stage in the history of the formation of Ukrainian grammatical terminology was marked in 1596 by the work of Lavrentiy Zyzania (1560-1632). This is a systematic textbook, which is the first attempt to consistently lay out and normalize the morphology of the Church Slavonic language. The author borrowed the structure and theoretical part of his work on the famous grammar of Greek and Latin languages. The systematization of L. Zyzaini's linguistic material became for M. Smotrytsky an example for creating his own original classification of parts of speech. M. Smotrytskyi who, having a more thorough education and linguistic training, brought up in the spirit of the classical grammatical tradition, became deeply aware of the peculiarities of the Slavic grammatical system and better understood the differences between living and literary Ukrainian language from Church Slavonic.

The work of Meletiy Smotrytskyi (1577-1633) contains a detailed description of composition, words, sentences. As the researcher of the historiography of Ukrainian linguistics V. Nimchuk notes: "As a terminology creator, M. Smotrytskyi had no equal in the history of ancient Slavic studies. The fact that a great number of created and introduced by him terms in the unchanged or improved form has been functioning even now in many Slavic terminology systems, is a convincing proof of its scientific nature" (Німчук 1985). One more merit of M. Smotrytskyi's introduction of the local 
case is "a сказательный падежъ" thus improving the basis of the modern casesystem. As we see, the scientist was able not only to identify differences in the language but also to comprehend and formalize them theoretically.

"Грамматыка" by I. Uzhevych is characterized by an original description of their grammatical categories. The author sought to find the defining features of these categories characteristic of the Ukrainian language, which was compared in languages such as Latin, Polish, rarely in Greek, and sometimes Jewish (Граматыка 1643: 5). There was an urgent need to create scientific terms that would correctly reflect the living folk language and would be inherent and understandable. On the Western Ukrainian lands, there were numerous grammatical works, the authors of which defended the right of the Ukrainian language to return to popular schools, in which grammatical terminology "played an important role in the development of linguistics, since it transmitted the Western European experience" (Десюк 2007: 258-260).

The active process of the creation of Ukrainian terms continues in the twentieth century, and the works of S. SmalStotskyi and F. Gartner's "Руска грамиmuкa" (Rus' grammar) (1893) played an important role in this process. The expert in Ukrainian terminology I. Ohiyenko in the Historical Dictionary in 1908 wrote: "The grammar of S. Smal-Stotskyi and F. Gartner is the first grammar written in phonetic spelling. These scientists are considered to be the creators of the present terminology" (Огієнко 1908: 20).
The problem of systematization and standardization of linguistic terminology was very relevant at the end of the $20^{\text {th }}$ century, as a large number of new concepts and terms appeared, and some of the traditional terms acquired new meanings (Москаленко 1959: 87). The register of the Dictionary of Linguistic Terms for the first time introduced a certain number of new terms, mostly borrowed ones (гралема, валентність, волюнтатив, індикатив, ілператив, каузативні дієслова, сингулятив, кон'юнкmuв) (grammeme, valency, volitional mood, indicative, imperative, causative verb, singular, conjunct, etc.). The issue of the establishment of grammatical terminology in general and morphological in particular remains relevant at the beginning of the $21^{\text {th }}$ century. In the book "Theoretical Morphology of the Ukrainian Language" (Вихованець 2004), the authors consider the central issues of morphology, morphological units, and morphological word-formation, presenting not quite a traditional, new interpretation of parts of speech and morphological categories.

Consequently, the modern stage of Ukrainian linguistics is characterized by numerous achievements of domestic scientists demonstrating the emergence of new scientific directions and approaches to the study of morphology, clarification and a new definition of grammatical terms. Greek and Roman grammatists created a clear system of parts of speech, which became for European linguist researchers an inexhaustible source of definitions, categories, concepts, rules, samples, and grammatical terms. The broad understanding of the ancient scholars of 
grammar as a branch of philological knowledge, and the formation of morphology as its separate and main section, largely predetermined the development of the Ukrainian grammatical tradition at the early stages of development.

\section{CONCLUSIONS}

We have grounds to assert that at different stages of development the morphology terminology system changes. In addition, terms definitions and their lexical expression; become more concrete. In the process of standardizing the system of morphological categories terms, we observe the active rooting of words created according to the norms of the Ukrainian language, which make up one-third of the names of the accidents of parts of speech. Innovations that characterize specific peculiarities of the native language are most closely related to the system of the verb, as well as the official parts of speech and their categories. About 70 percent of the terminology of grammatical categories with specific Ukrainian names is created by semantic imitation of ancient, in particular, Greek terms; 30 percent of the vocabulary is synonymous with Latin basics. The ratio of the use of terminological vocabulary

\section{Literature and References}

1. Adelphotes: die erste gedruckte griechischkirchenslavische Grammatik. 1591. Lviv-Lemberg, das Faksimile erweiterte Aufl. München: Sagner, 1988.

2. Aristoteles. 1982. Poetik. Griechisch. Deutsch; übersetzt und herausgegeben von M. Fuhrmann; Philipp Reclam Jun. Stuttgart.

3. Barwick Karl. 1957. Probleme der stoischen Sprachlehre und Rhetorik. Abhandl. des Sächs. Akad. der Wissenschaft. Philol-histor. Klasse. Bd. 49. Hf. 3. Berlin: 1-86. in the ancient tradition and Ukrainian linguistics varies from the point of view of the specialized terminological meaning and terminologized commonly used words. If for the Greek-Roman concept of terminology it was peculiar to give special meaning to everyday commonly used words, then the Ukrainian names of parts of speech have a strictly terminological meaning, and the names of 90 percent of grammatical categories are terminologically commonly used words.

At the beginning of the $20^{\text {th }}$ century Ukrainian linguistics experienced the period of active creation of grammatical terms on a national basis, which was oriented to its own linguistic resources. That is how the domestic morphological terminology emerged. Also, new termsinternationalisms are also actively used in grammar, which facilitate the entry of Ukrainian linguistic science into the European scientific context.

4. Diogenis Laertii. 1872. De clarorum philosophorum vitis, dogmatibus et apophtegmatis libri X, rec. C. Gabr. Cobert. Paris : A. Firmin Dilot.

5. Gentinetta Peter M. 1961. Zur Sprachbetrachtung bei den Sophisten und in der stoisch-hellenistischen Zeit. Winterthur.

6. Grammatici Latini. 1857-1880. Edited by H. Keil. V. 1-7. Lipsiae.

7. Jeep Ludwig. 1896. Zur Geschichte der Lehre von den Redeteilen bei den lateinischen Grammatikern. XVIII Band. Heidelberg. 
8. Platon <http: //www.philosophy.ru/library/ plato/sofist.html>

9. Platonis Opera. 1910. Scriptorum classicorum bibliotheca Oxoniensis. T. 1 Sophista, Cratylus; T. 2 Parmenides / Rec. J. Burnet. Oxonii.

10. Pohlenz Max. 1939. Die Begründung der abendländischen Sprachlehre durch die Stoa. Nachrichten von der Gesellschaft der Wissenschaft zu Göttingen. Philologisch-historische Klasse. Fachgruppe 1: Altertumswissenschaft. Bd. 3. № 6: 151-198.

11. Varronis M. Terenti. 1910. De lingua Latina quae supersunt, rec. G. Gotz et F. Schöll. Lipsiae: B. G. Teubner. <https://archive.org/details/ mterentivarroni00mlgoog $>$

12. Амирова Тамара А. 1975. Очерки по истории иингвистики. Б. А. Ольховиков, Ю. В. Рождественский. Москва: Наука.

13. Вихованець Іван. 2004. Теоретична морфологія української мови: академічна граматика української мови. К. Городенська, І. Вихованець (ред.). Київ: Пульсари.

14. Грам. 1591. Грамматіка доброглаголиваго еллинословенскаго языка [Адельфотес]. Пьвів, 1591.

15. Грам. 1596. Грамматіка словенска $А$. Зизанія: <http://www.izbornyk.org.ua /ukrpoetry / anto15.htm\#lz2>

16. Грам. 1619. Грамматіки славенския правилноє сунтагма М. Смотрицького <http: //litopys.org.ua/smotrgram/sm.htm>

17. Грам. 1643 Граматыка словенская I. Ужевича. Париж, 1643 (паризький рукопис); 1645 (арраський рукопис). І.К. Білодід, Є.М. Кудрицький (підгот. до друку). Київ: Наук. думка, 1970.

18. Есперсен Отто. 1958. Философия грамматики. Москва: Изд-во иностр. лит.

19. Лесюк Микола. 2007. Становдення дінгвіс- тичної термінології в Галичині. Украӥнська термінологія і сучасність : зб. наук. пр. Вип. VII. Київ: КНЕУ: 257-262.

20. Москаленко Надія А. 1959. Нарис історії української граматичної термінології. Київ: Рад. школа.

21. Німчук Василь В. 1985. Мовознавство на Україні в XVI-XVII ст. Київ: Наук. думка. $<$ http://litopys.org.ua/nimchuk/nim.htm>

22. Німчук Василь В. 2002. Проблеми українського правопису XX - початку XXI ст. Київ: Наук. думка.

23. Огієнко Іван. 1908. Українська граматична термінологія. Історичний словник української граматичної термінології з передмовою про історію розвитку їі. Київ.

24. Оленич Роман М. 1962. Вчення Діонісія Фракійця про частини мови. Збірник робіт аспірантів романо-германської $і$ класичної фiлології. Дьвів: В-во Львівськ. ун-ту.

25. Оленич Роман М. 1973. Прісціан і антична граматика. Аьвів: В-во Аьвівськ. ун-ту.

26. Панько Таміла I. 1994. Українське термінознавство. І.М. Кочан, Г.П. Мацюк. Львів: Світ.

27. Полюга Світлана М. 2018. Автентична позиція граматики "Adelfotes": виклики та перспективи. - Чернівці-Сучава. № 3 (19): 14-18. <http://dx.doi.org/10.24061/2411-6181.3.2018.49.>

28. Полюга Світлана М. 2013. Греко-римська традиція у становленні української граматичної термінології (на матеріалі морфологіi): автореф. дис на здобуття наук. ступеня канд. філол. наук: спец. 10.02.14. Київ.

29. Тимченко Євген. 1907. Українська граматика. Київ: 3 друк. УАН, 179 с. <http://shron1. chtyvo.org.ua/Tymchenko Yevhen/Ukrainska_ hramatyka.pdf> 